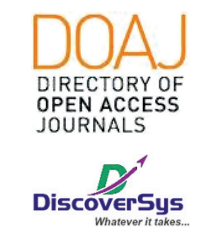

Published by DiscoverSys

\section{Karakteristik klinikopatologi osteosarkoma berdasarkan usia, jenis kelamin, lokasi, dan tipe histopatologi di Laboratorium Patologi Anatomi RSUP Sanglah Denpasar tahun 2012 -2016}

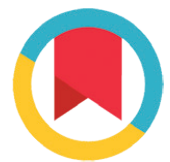

CrossMark

\author{
Putu Agus Aryanda Putra, ${ }^{1 *}$ Anak Agung Ngurah Susraini, ${ }^{2}$ I Wayan Juli Sumadi ${ }^{2}$
}

\title{
ABSTRACT
}

Background: 0steosarcoma was the most common primary bone tumor, and there are only a few studies discussed the clinicopathological characteristics of Osteosarcoma.

Aim: This study aimed to determine the clinicopathological features of Osteosarcoma based on age, sex, type, and the location in Anatomical Pathology Laboratories Sanglah Hospital Denpasar in 2012 - 2016. Method: This research was a cross sectional descriptive study which obtains data from the medical record in Anatomical Pathology laboratories Sanglah Hospital Denpasar in 2012 - 2016. The total sample is 44 cases by total sampling technique. The data were processed using SPSS version 20.

Result: In this study, the majority of Osteosarcoma patients were in age group $0-24$ years as many as 30 cases (68.2\%) and rarely found in the age group $49-72$ years for 2 cases (4.5\%). 0steosarcoma was slightly higher in a male about 23 cases (52.3\%) and 21 cases in female (47.7\%). Conclusion: the Histopathological type that mostly found was Conventional Osteosarcoma as many as 41 cases (93.2\%) and the most common site of Osteosarcoma was in femur about 24 cases (52.2\%).

Keywords: Osteosarcoma, clinical pathology, Sanglah Hospital

Cite This Article: Putra, P.A.A., Susraini, A.A.N., Sumadi, I.W.J. 2020. Karakteristik klinikopatologi osteosarkoma berdasarkan usia, jenis kelamin, lokasi, dan tipe histopatologi di Laboratorium Patologi Anatomi RSUP Sanglah Denpasar tahun 2012 -2016. Intisari Sains Medis 11(2): 923-927. DOl: 10.15562/ism.v11i2.203

\section{ABSTRAK}

Osteosarkoma merupakan tumor primer pada tulang yang paling sering ditemukan, namun tidak banyak penelitian yang hanya membahas karakteristik klinikopatologi 0steosarkoma.

Tujuan: Tujuan penelitian ini adalah untuk mengetahui karakteristik klinikopatologi Osteosarkoma berdasarkan usia, jenis kelamin, tipe, dan lokasi di Laboratorium Patologi Anatomi RSUP Sanglah RSUP Sanglah Denpasar pada tahun 2012 - 2016.

Metode: Penelitian ini merupakan studi deskriptif cross sectional yang dilaksanakan di Laboratorium Patologi Anatomi RSUP Sanglah Denpasar menggunakan catatan rekam medis periode tahun 2012 -2016. Teknik pengambilan sampel menggunakan total sampling, dengan total jumlah sampel sebanyak 44 orang. Data diolah menggunakan SPSS versi 20.

Penderita Hasil: Osteosarkoma pada penelitian ini paling sering ditemukan pada kelompok usia 0 - 24 tahun sebanyak 30 kasus $(68,2 \%)$ dan paling sedikit pada kelompok usia 49 - 72 tahun terdapat 2 kasus (4,5\%). Jumlah kasus 0steosarkoma sedikit lebih tinggi kasusnya pada pria yaitu, sebanyak 23 kasus $(52,3 \%)$ sedangkan pada wanita ditemukan sebanyak 21 kasus (47,7\%).

Simpulan: Tipe histopatologi yang paling sering ditemukan adalah Conventional Osteosarcoma sebanyak 41 kasus $(93,2 \%)$ dan lokasi tersering pada tulang femur sebanyak 24 kasus $(52,2 \%)$.
${ }^{1}$ Program Studi Pendidikan Dokter, Fakultas Kedokteran, Universitas Udayana

${ }^{2}$ Bagian Patologi Anatomi RSUP Sanglah Denpasar

\section{${ }^{*}$ Correspondence to:} Putu Agus Aryanda Putra, Program Studi Pendidikan Dokter, Fakultas Kedokteran, Universitas Udayana aryanda96@icloud.com

Diterima: 06-04-2018 Disetujui: $15-06-2018$ Diterbitkan: 01-08-2020

Kata kunci: Osteosarkoma, klinikopatologi, RSUP Sanglah

Cite Pasal Ini: Putra, P.A.A., Susraini, A.A.N., Sumadi, I.W.J. 2020. Karakteristik klinikopatologi osteosarkoma berdasarkan usia, jenis kelamin, Iokasi, dan tipe histopatologi di Laboratorium Patologi Anatomi RSUP Sanglah Denpasar tahun 2012 -2016. Intisari Sains Medis 11(2): 923-927. D0l: 10.15562/ism.v11i2.203

\section{PENDAHULUAN}

Kanker merupakan suatu kelainan pada tingkat biomolekular yang menyebabkan sel dapat tumbuh tidak terkendali sehingga dapat menyerang jaringan lain di sekitarnya dan tidak menutup kemungkinan untuk dapat bermigrasi menuju jaringan tubuh lainnya. Terdapat banyak jenis tumor pada tulang, jenis tumor tersebut dapat diklasifikasikan menjadi, tumor jinak, tumor ganas atau yang bisa disebut kanker, dan ada pula tumor ganas sekunder yang disebabkan oleh penyebaran dari salah satu organ atau disebut metastasis. ${ }^{1}$ 
Osteosarkoma merupakan tumor ganas primer pada tulang yang paling sering muncul $(0,2 \%$ dari semua jenis tumor ganas pada tulang), dengan angka insiden 3 kasus per satu juta populasi per tahun. ${ }^{2}$ Kasus Osteosarkoma biasanya terjadi pada usia muda dengan puncak insiden pada dekade kedua, tetapi ada juga yang terjadi pada usia tua. Angka kejadian Osteosarkoma pada anak-anak dan remaja terlihat relatif hampir sama di seluruh dunia. ${ }^{3}$ Telah diketahui Osteosarkoma lebih umum terjadi pada pria daripada wanita baik untuk usia muda, maupun usia tua.

Osteosarkoma berdasarkan lokasinya dapat dibedakan manjadi dua yaitu, intramedullary dan extramedullary atau di permukaan tulang. Osteosarkoma diklasifikasikan oleh WHO, yaitu sebagai berikut: 1) Conventional Ostoesarcoma yang terdiri dari Osteoblastic Osteosarcoma, Chondroblastic Osteosarcoma, dan Fibroblastic Osteosarcoma; 2) Telangietatic Osteosarcoma; 3) Small Cell Osteosarcoma; 4) Low Grade Central Osteosarcoma; 5) Secondary Osteosarcoma yang terdiri dari Paget Osteosarcoma, Post-radiation Osteosarcoma, dan Osteosarcoma pada berbagai penyakit tulang; 6) Parosteal Osteosarcoma; 7) Periosteal Osteosarcoma; 8) High Grade Surface Osteosarcoma. ${ }^{4}$

Tipe Conventional Osteosarcoma merupakan yang paling banyak ditemukan pada usia dekade kedua di bawah 25 tahun, selain itu ditemukan juga pada usia di atas 40 tahun yang disertai dengan faktor predisposisi seperti Paget's disease dan Post-radiation Osteosarcoma. Ada pula tipe Osteosarkoma lainnya, namun kasusnya tidak sebanyak Conventional Osteosarcoma. Telangiectatic Osteosarcoma, Small Cell Osteosarcoma, dan Low Grade Central Osteosarcoma merupakan tipe Osteosarkoma yang jarang ditemukan. Secondary Osteosarcoma merupakan tipe Osteosarkoma yang ditemukan akibat adanya abnormalitas lainnya seperti Paget's disease dan post-radiation sarcoma dan tipe ini biasanya ditemukan pada kelompok usia tua. ${ }^{4}$

Berdasarkan lokasinya, terdapat tipe Osteosarkoma yang tumbuh di permukaan tulang seperti Parosteal Osteosarcoma, Periosteal Osteosarcoma, dan High Grade Surface Osteosarkoma. Parosteal Osteosarcoma merupakan salah satu tipe Osteosarkoma yang lokasi tumbuhnya di permukaan tulang, tipe ini merupakan yang paling umum ditemukan berdasarkan lokasinya yang ada di permukaan tulang namun, Parosteal Osteosarcoma lebih sering ditemukan pada perempuan daripada laki-laki tidak seperti tipe Osteosarkoma lainnya yang dominan ditemukan pada laki-laki. Angka kejadian Periosteal Osteosarcoma sangatlah jarang namun lebih sering ditemukan daripada High Grade Surface. ${ }^{4}$

Etiologi dari Osteosarkoma ini masih belum jelas dan hanya beberapa faktor risiko yang diketahui, seperti faktor lingkungan dan faktor genetik. Untuk sementara ini beberapa faktor diduga memiliki peranan penting dalam terjadinya Osteosarkoma, seperti terjadinya ekspresi gen Met dan Fos secara berlebihan, mutasi gen TP53, dan beberapa penyakit bawaan sejak lahir yang dicurigai dapat menimbulkan terjadinya Osteosarkoma seperti Retinoblastoma Herediter. ${ }^{4}$ Paparan lingkungan juga memiliki peranan penting dalam terjadinya Osteosarkoma, seperti paparan radiasi yang dapat menimbulkan terjadinya mutasi gen sehingga membentuk suatu keganasan. Dengan kurangnya pengetahuan mengenai etiologi dan faktor risiko, cukup sulit untuk melakukan pencegahan terhadap penyakit ini. $^{2}$

Selain dari temuan gejala klinis hasil anamnesis dan pemeriksaan fisik, beberapa metode diagnosis yang biasa dilakukan yaitu, pemeriksaan radiografi, dan pemeriksaan histopatologi tulang dengan melihat tampilan tumor dan sel tumor tersebut untuk dapat mengarahkan diagnosis ke Osteosarkoma. Pada pemeriksaan radiografi akan ditemukan gambaran yang khas dan dapat menunjukkan tipe Ostoesarkoma secara spesifik, seperti gambaran Sun-ray, fraktur pada tulang, dan Codman's triangle namun, karena banyaknya tipe Osteosarkoma dan jenis tumor tulang lainnya dapat membingungkan sehingga diagnosis belum dapat ditegakkan. Hal itu tidak menutup kemungkinan terjadinya kesalahan diagnosis karena adanya kemiripan gejala klinis dan gambaran radiografi. Maka dari itu, pemeriksaan patologi anatomi dilakukan salah satunya adalah dengan Fine Needle Aspiration Biopsy (FNAB) untuk melihat gambaran histopatologi sel tumor sehingga dapat mengarahkan ke salah satu tipe Osteosarkoma yang sesuai sehingga diagnosis dapat ditegakkan dengan begitu manajemen terhadap Osteosarkoma dapat dilakukan dengan tepat. Penentuan modalitas terapi sangat berpengaruh terhadap morbiditas dan mortalitas pasien dengan Osteosarkoma. ${ }^{2}$ Survival rate Osteosarkoma bervariasi berdasarkan umur, jenis kelamin, stadium dari penyakitnya, dan lokasi secara anatomi. Untuk anak-anak dan remaja survival rate-nya tidak berbeda di kebanyakan negara. ${ }^{5}$

Di Bali belum terdapat penelitian yang spesifik mengenai karakteristik klinikopatologi Osteosarkoma. Sehingga penelitian ini diperlukan mengenai karakteristik klinopatologi Osteosarkoma di RSUP Sanglah Denpasar, Bali yang didapat dari data rekam medis Laboratorium Patologi Anatomi RSUP Sanglah Denpsar tahun 2012-2016. 


\section{METODE PENELITIAN}

Penelitian ini menggunakan desain cross-sectional deskriptif yang dilakukan di Laboratorium Patologi Anatomi RSUP Sanglah Denpasar, Bali, pada bulan September hingga November 2017. Penelitian ini menggunakan teknik total sampling dimana seluruh populasi terjangkau dimasukkan sebagai sampel yaitu semua kasus dengan diagnosis Osteosarkoma yang diambil dari rekam medis Laboratorium Patologi Anatomi di RSUP Sanglah Denpasar pada tahun 2012-2016. Adapun karakteristik yang digunakan pada penelitian ini meliputi usia, jenis kelamin, lokasi osteosarkoma, dan tipe histopatologi osteosarkoma yang tercantum dalam rekam medis Laboratorium Patologi Anatomi RSUP Sanglah Denpasar sebagai instrumen penelitian. Hasil penelitian ini diolah menggunakan SPSS versi 20 dan ditampilkan dalam bentuk tabel, grafik, dan narasi. Penelitian ini telah disetujui oleh Komisi Etik Litbang Fakultas Kedokteran Universitas Udayana dengan nomor 2017.01.1.0580.

\section{HASIL}

\section{Karakteristik Berdasarkan Usia}

Berdasarkan klasifikasi usia oleh Departemen Kesehatan Republik Indonesia, ketegori usia dibagi menjadi 3 kelompok yaitu 0 - 24 tahun,
$25-48$ tahun, $49-72$ tahun. Karakteristik usia pasien dapat dilihat pada Tabel 1 .

Dalam tabel 5.1 di atas dapat dilihat selama periode tersebut jumlah penderita Osteosarkoma terbanyak adalah kelompok usia $0-24$ tahun, pada tahun 2012 sebanyak 3 kasus (75,0\%), tahun 2013 sebanyak 9 kasus $(81,8 \%)$, tahun 2014 sebanyak 5 kasus (71,4\%), tahun 2015 sebanyak 7 kasus (63,6\%), dan tahun 2016 sebanyak 6 kasus (54,5\%).

\section{Karakteristik Berdasarkan Jenis Kelamin}

Berdasarkan jenis kelamin yang tercatat di Laboratorium Patologi Anatomi RSUP Sanglah perbandingan antara pria dan wanita tidak terlalu jauh berbeda dimana, kasus Osteosarkoma pada pria sebanyak 23 kasus (52,3\%) dan pada wanita sebanyak 21 kasus (47,7\%) (Tabel 2).

\section{Karakteristik Berdasarkan Lokasi}

Berdasarkan lokasinya dapat dilihat pada Tabel 3. Osteosarkoma paling sering ditemukkan di tulang panjang femur, cruris, tibia, dan humerus. Osteosarkoma dominan ditemukan pada femur sebanyak 23 kasus $(52,2 \%)$ dengan pembagian regio distal sebanyak 21 kasus $(47,7 \%)$ dan regio proximal sebanyak 2 kasus (4,5\%). Lokasi lain yang cukup sering ditemukan seperti, pada cruris sebanyak 7 kasus (15,9\%), pada tibia sebanyak 4 kasus $(9,1 \%)$ dengan pembagian regio distal 1 kasus

Tabel 1 Karakteristik Klinikopatologi Ostesarkoma berdasarkan Usia ( $N=44)$

\begin{tabular}{|c|c|c|c|c|c|c|c|c|}
\hline \multirow[b]{3}{*}{ Tahun } & \multicolumn{8}{|c|}{ Usia } \\
\hline & \multicolumn{2}{|c|}{$0-24$ tahun } & \multicolumn{2}{|c|}{25 - 48 tahun } & \multicolumn{2}{|c|}{$49-72$ tahun } & \multicolumn{2}{|c|}{ Total } \\
\hline & $\mathbf{n}$ & $\%$ & $\mathbf{n}$ & $\%$ & $\mathbf{n}$ & $\%$ & $\mathbf{N}$ & $\%$ \\
\hline 2012 & 3 & 75,0 & 1 & 25,0 & 0 & 0 & 4 & 100 \\
\hline 2013 & 9 & 81,8 & 2 & 18,2 & 0 & 0 & 11 & 100 \\
\hline 2014 & 5 & 71,4 & 2 & 28,6 & 0 & 0 & 7 & 100 \\
\hline 2015 & 7 & 63,6 & 4 & 36,4 & 0 & 0 & 11 & 100 \\
\hline 2016 & 6 & 54,5 & 3 & 27,3 & 2 & 18,2 & 11 & 100 \\
\hline Total & 30 & 68,2 & 12 & 27,3 & 2 & 4,5 & 44 & 100 \\
\hline
\end{tabular}

Tabel 2 Karakteristik Klinikopatologi Ostesarkoma berdasarkan Jenis Kelamin ( $N=44)$

\begin{tabular}{|c|c|c|c|c|c|c|}
\hline \multirow[b]{3}{*}{ Tahun } & \multicolumn{6}{|c|}{ Jenis Kelamin } \\
\hline & \multicolumn{2}{|c|}{ Pria } & \multicolumn{2}{|c|}{ Wanita } & \multicolumn{2}{|c|}{ Total } \\
\hline & $\mathbf{n}$ & $\%$ & $\mathbf{n}$ & $\%$ & $\mathbf{N}$ & $\%$ \\
\hline 2012 & 1 & 25,0 & 3 & 75,0 & 4 & 100 \\
\hline 2013 & 4 & 36,4 & 7 & 63,6 & 11 & 100 \\
\hline 2014 & 4 & 57,1 & 3 & 42,9 & 7 & 100 \\
\hline 2015 & 6 & 54,5 & 5 & 45,5 & 11 & 100 \\
\hline 2016 & 8 & 72,7 & 3 & 27,3 & 11 & 100 \\
\hline Total & 23 & 52,3 & 21 & 47,7 & 44 & 100 \\
\hline
\end{tabular}


Tabel 3 Karakteristik Klinikopatologi Ostesarkoma berdasarkan Lokasi ( $\mathrm{N}=44)$

\begin{tabular}{lcc}
\hline Lokasi & N & Frekuensi (\%) \\
\hline Cruris & 7 & 15,9 \\
Femur $\quad$ Distal & 21 & \\
$\quad$ Proximal & 2 & 47,7 \\
Fibula & 1 & 4,5 \\
Gluteus & 1 & 2,3 \\
Hemitoraks & 1 & 2,3 \\
Humerus & 3 & 2,3 \\
Ilium & 2 & 6,8 \\
Mandibula & 2 & 4,5 \\
Tibia & & 4,5 \\
Distal & 1 & \\
Proximal & 3 & 2,3 \\
Total & 44 & 6,8 \\
\hline
\end{tabular}

Tabel 4 Karakteristik Klinikopatologi Ostesarkoma berdasarkan Tipe Histopatologi $(\mathrm{N}=44)$

\begin{tabular}{lcc}
\hline Tipe & N & Frekuensi (\%) \\
\hline Conventional Osteosarcoma & 41 & 93,2 \\
Small Cell Osteosarcoma & 1 & 2,3 \\
Parosteal Osteosarcoma & 1 & 2,3 \\
Secondary Osteosarcoma & 1 & 2,3 \\
Total & 44 & 100 \\
\hline
\end{tabular}

Tabel 5 Karakteristik Klinikopatologi Ostesarkoma berdasarkan subtipe Conventional Osteosarcoma ( $\mathrm{N}=41)$

\begin{tabular}{lcc}
\hline Subtipe & N & Frekuensi (\%) \\
\hline Osteoblastic Osteosarcoma & 9 & 22,0 \\
Chondroblastic Osteosarcoma & 9 & 22,0 \\
Fibroblastic Osteosarcoma & 5 & 12,2 \\
Mixed type & 18 & 43,9 \\
Total & 41 & 100 \\
\hline
\end{tabular}

$(2,3 \%)$ dan regio proximal 3 kasus $(6,8 \%)$, dan pada humerus sebanyak 3 kasus $(6,8 \%)$.

\section{Karakteristik Berdasarkan Tipe Histopatologi}

Berdasarkan tipe histopatologi yang tercatat di Laboratorium Patologi Anatomi RSUP Sanglah Denpasar dapat dilihat pada Tabel 4. Tipe Osteosarkoma yang paling dominan ditemukan yaitu tipe Conventional Osteosarcoma sebanyak 41 kasus (93,2\%). Terdapat tipe Osteosarakoma lainnya seperti, Small Cell Osteosarcoma hanya
1 kasus (2,3\%), Parosteal Osteosarcoma 1 kasus (2,3\%), dan Secondary Osteosarcoma ditemukan hanya 1 kasus $(2,3 \%)$.

Conventional Osteosarcoma terdiri dari 3 subtipe yaitu, Osteoblastic Osteosarcoma, Chondroblastic Osteosarcoma, Fibroblastic Osteosarcoma. Dapat dilihat pada Tabel 5, Osteoblastic Osteosarcoma ditemukan sebanyak 9 kasus (22\%), Chondroblastic Osteosarcoma sebanyak 9 kasus (22\%), dan Fibroblastic Osteosarcoma sebanyak 5 kasus $(12,2 \%)$, dan sebanyak 18 kasus (43,9\%) mixed type Conventional Osteosarcoma yang belum dapat diketahui secara pasti subtipenya.

\section{PEMBAHASAN}

\section{Karakteristik Berdasarkan Usia}

Berdasarkan karakteristik usia, penelitian ini sesuai dengan Mirabello, dkk. (2009) yang menyatakan puncak kejadian Ostesarkoma yaitu pada anakanak dan remaja pada usia $0-24$ tahun. ${ }^{6}$ Hal yang sama juga terdapat dalam penelitian Sihombing dkk. yang dilakukan di Rumah Sakit Dr Cipto Mangunkusumo Jakarta dalam periode waktu 1998 - 2008, yang dimana ditemukan sebanyak 23 pasien Osteosarkoma dengan rentang usia antara 9 - 15 tahun. Faktor usia berkaitan dengan jumlah kasus Osteosarkoma, yang mana banyak ditemukan pada anak - anak dan remaja usia $0-24$ tahun. $^{7}$ Beberapa studi menunjukkan hubungan pertumbuhan tulang saat pubertas dengan perkembangan Osteosarkoma. ${ }^{8}$ Faktor genetik diduga memiliki peran dalam terjadinya Osteosarkoma ini, seperti mutasi germline kromosom TP53 telah ditemukan pada $50 \%$ penderita kanker. ${ }^{9}$ Pada periode waktu 2012 - 2016 kelompok usia 25 - 48 tahun ditemukan sebanyak 12 kasus (27,3\%) dan kelompok usia 49 72 tahun sebanyak 2 kasus (4,5\%). Kelompok usia ini memiliki risiko mengalami Osteosarkoma lebih rendah karena pertumbuhan tulang yang sudah terhenti sehingga kecil kemungkinan terjadinya mutasi sel tulang. Namun, faktor lingkungan juga dapat memudahkan terjadinya Osteosarkoma pada kelompok usia ini seperti, paparan radiasi dapat meningkatkan pertumbuhan sel kanker. Radiasi memiliki peranan sekitar 2\% terhadap terjadinya Osteosarkoma. ${ }^{2}$ Paparan terhadap zat kimia juga dihubungkan dengan terjadinya Osteosarkoma seperti, methylcholanthrene dan chromium salts, beryllium oxide, zinc beryllium silicate, asbestos, dan aniline dyes. ${ }^{8}$

\section{Karakteristik Berdasarkan Jenis Kelamin}

Berdasarkan karakteristiknya yang dilihat dari jenis kelamin, studi dari Moesbar pada tahun 2006 yang dilakukan di RSUP Haji Adam Malik Medan pada 
periode waktu Januari 2002 - Juni 2006 ditemukan 27 kasus tumor tulang dan 13 kasus adalah Osteosarkoma, 8 kasus diantaranya ditemukan pada laki-laki dan 5 kasus lagi ditemukan pada wanita. ${ }^{10}$

Kedua jenis kelamin terlihat memiliki risiko yang sama untuk menderita penyakit Osteosarkoma ini. Hormon esterogen pada wanita dan hormon testosteron pada pria memiliki efek pada pertumbuhan tulang. ${ }^{11}$ Estrogen mulai diproduksi pada saat awal pubertas yang mana meningkatkan pertumbuhan tulang, kemudian pada akhir pubertas akan menghentikan pertumbuhan tulang karena menutupnya lempengan kartilago pada tulang tersebut. Testosteron memiliki peranan penting untuk pertembuhan tulang melalui efek langsung terhadap tulang dan kemampuan untuk menstimulasi pertumbuhan otot. Testosteron dapat dikonversi menjadi estrogen di dalam sel lemak. Estrogen ini sangat penting untuk tulang bagi pria dan wanita, pada pria usia tua ditemukan kadar estrogen yang lebih tinggi dibandingkan dengan wanita yang sudah mengalami menopause. ${ }^{12}$

\section{Karakteristik Berdasarkan Lokasi}

Berdasarkan lokasi Osteosarkoma, hasil studi ini ditemukan serupa dengan penelitian Fletcher pada tahun 2013 yang menyatakan bahwa Osteosarkoma paling banyak ditemukan pada tulang panjang seperti femur distal, tibia proximal, dan proximal humerus. ${ }^{4}$

Osteosarkoma juga bisa ditemukan di beberapa tulang selain tulang panjang seperti pada gluteus ditemukan 1 kasus (2,3\%), pada hemitoraks ditemukan 1 kasus (2,3\%), pada ilium ditemukan 2 kasus (4,5\%), dan pada mandibula ditemukan 2 kasus (4,5\%). Hal ini menunjukkan Osteosarkoma dapat terjadi di semua jenis tulang, baik itu tulang panjang maupun tulang pendek namun angka insidennya lebih tinggi pada tulang panjang.

\section{Karakteristik Berdasarkan Tipe Histopatologi}

Berdasarkan tipe histopatologi, hasil penelitian ini juga didapatkan serupa dengan penelitian Fletcher, dkk. (2013), yang melaporkan bahwa Conventional Osteosarcoma ditemukan 60\% terjadi pada usia dekade kedua di bawah 25 tahun, dan ditemukan juga sebanyak $30 \%$ terjadi pada usia di atas 40 tahun yang disertai dengan faktor predisposisi seperti Paget's disease dan post-radiation sarcoma. ${ }^{4}$

\section{SIMPULAN}

Pada penelitian ini, dapat disimpulkan bahwa karakteristik klinikopatologi osteosarkoma berdasarkan usia lebih banyak ditemukan pada kelompok usia 0 - 24 tahun; jenis kelamin antara pria dan wanita tidak terlalu jauh berbeda; lokasi Osteosarkoma yang paling sering ditemukan pada tulang femur terutama pada region distal., dan tipe histopatologi yang paling sering ditemukan adalah Conventional Osteosarcoma.

\section{DAFTAR PUSTAKA}

1. Mehlman. Osteosarcoma: Background, Pathophysiology, Etiology [Internet]. Medscape; 2014 [cited 2017 Dec 19]. Available from: http://emedicine.medscape.com/ article/1256857-overview\#a8

2. Picci P. Osteosarcoma (Osteogenic sarcoma). Orphanet Journal of Rare Diseases. 2007;2(1):4-7.

3. Mirabello L, Troisi RJ, Savage $\mathrm{S}$ a. International osteosarcoma incidence patterns in children and adolescents, middle ages, and elderly persons. International Journal of Cancer. 2011;125(1):229-34.

4. Fletcher CDM, Hogendoorn PCW, Mertens F, Bridge J A. WHO Classification of Tumours of Soft Tissue and Bone. 4th ed. Geneva: World Health Organization; 2013. 281-295 p.

5. Savage S a., Mirabello L. Using epidemiology and genomics to understand osteosarcoma etiology. Sarcoma. 2011;2011: 14-6.

6. Mirabello L, Troisi RJ, Savage S. Osteosarcoma incidence and survival improvement. Cancer. 2009;115(7):1531-43.

7. Sihombing TY, Windiastuti E, Gatot D. Osteosarkoma pada Anak di RS. Dr Cipto Mangunkusumo Jakarta. Sari Pediatri. 2009;11(3):179-83.

8. Choong PFM, Broadhead ML, Clark JCM, Myers DE, Dass CR. The molecular pathogenesis of osteosarcoma: A review. Sarcoma. 2011;2011:1-12.

9. Calvert GT, Randall RL, Jones KB, Cannon-Albright L, Lessnick S, Schiffman JD. At-risk populations for osteosarcoma: The syndromes and beyond. Sarcoma. 2012;2012:1-9.

10. Moesbar N, Bedah D, Adam FRH. Profil Tumor Tulang di RSUP Haji Adam Malik Medan. Majalah Kedokteran Nusantara. 2006;39(3):217-20.

11. Falahati-Nini a., Riggs BL, Atkinson EJ, O’Fallon WM, Eastell R, Khosla S. Relative contributions of testosterone and estrogen in regulating bone resorption and formation in normal elderly men. Journal of Clinical Investigation. 2000;106(12):1553-60.

12. McGowam J, Raisz L, Noonan A, Elderkin A. Bone Health and Osteoporosis: A Report of the Surgeon General. Rockville: Department of Health and Human Services, Office of the Surgeon General; 2004. 28-29 p.

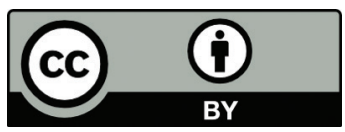

This work is licensed under a Creative Commons Attribution 